\title{
Investigating the impact of aerosol deposition on snowmelt over the Greenland Ice Sheet using a large-ensemble kernel
}

\author{
Yang Li and Mark G. Flanner \\ Climate and Space Sciences and Engineering, University of Michigan, Ann Arbor, Michigan, USA \\ Correspondence: Yang Li (yanglibj@umich.edu)
}

Received: 30 May 2018 - Discussion started: 9 July 2018

Revised: 8 October 2018 - Accepted: 19 October 2018 - Published: 7 November 2018

\begin{abstract}
Accelerating surface melt on the Greenland Ice Sheet (GrIS) has led to a doubling of Greenland's contribution to global sea level rise during recent decades. Black carbon (BC), dust, and other light-absorbing impurities (LAIs) darken the surface and enhance snowmelt by boosting the absorption of solar energy. It is therefore important for coupled aerosol-climate and ice sheet models to include snow darkening effects from LAI, and yet most do not. In this study, we conduct several thousand simulations with the Community Land Model (CLM) component of the Community Earth System Model (CESM) to characterize changes in melt runoff due to variations in the amount, timing, and nature (wet or dry) of BC deposition on the GrIS. From this large matrix of simulations, we develop a kernel relating runoff to the location, month, year (from 2006 to 2015), and magnitudes of $\mathrm{BC}$ concentration within precipitation and dry deposition flux. BC deposition during June-August causes the largest increase in annually integrated runoff, but winter deposition events also exert large (roughly half as great) runoff perturbations due to reexposure of impurities at the snow surface during summer melt. Current BC deposition fluxes simulated with the atmosphere component of CESM induce a climatological-mean increase in GrIS-wide runoff of $\sim 8 \mathrm{Gt} \mathrm{yr}^{-1}$, or $+6.8 \%$ relative to a paired simulation without $\mathrm{BC}$ deposition. We also provide linear equations that relate the increase in total runoff to GrIS-wide wet and dry $\mathrm{BC}$ deposition fluxes. It is our hope that the runoff kernel and simple equations provided here can be used to extend the utility of state-of-the-art aerosol models.
\end{abstract}

\section{Introduction}

The Greenland Ice Sheet (GrIS) holds ice the equivalent of about $7 \mathrm{~m}$ of sea level rise if it melts (Kintisch, 2017). During recent decades, the accelerating decline of the GrIS has doubled Greenland's contribution to global sea level rise to about $0.74 \mathrm{~mm} \mathrm{yr}^{-1}$ (Shepherd et al., 2012; Rignot and Kanagaratnam, 2006; van den Broeke et al., 2009; Kintisch, 2017). Mass loss from the GrIS is predicted to raise sea level by more than $20 \mathrm{~cm}$ by 2100 (Rignot et al., 2011; Dumont et al., 2014), imposing tremendous effects on global society.

Ice loss from the GrIS is caused by many physical and biological factors, including (1) increase in air temperature over the Arctic region, which accelerates surface melting; (2) declining surface albedo, which can be caused by a variety of effects including increased melt area, enhanced snow metamorphism, and accumulation of light-absorbing impurities (LAIs) (Tedesco et al., 2016; Box et al., 2012; Dumont et al., 2014; Keegan et al., 2014; Shimada et al., 2016; Polashenski et al., 2015); and (3) calving of icebergs and submarine melting due to ice dynamics and changes of ocean temperature (Krabill et al., 2004; Zwally et al., 2002; Dumont et al., 2014). Since 2005, surface melting has likely contributed more to ice loss than iceberg calving (Kintisch, 2017). Sources of LAIs include black carbon (BC), mineral dust, and algae and bacteria growing on the wet surface of the ice sheet, all of which darken the surface, boost the absorption of insolation, and enhance snowmelt.

$\mathrm{BC}$ is a major anthropogenic pollutant originating from fossil fuel combustion, open biomass burning, and biofuel use, and it is a key LAI because its solar absorptivity is extremely high (e.g., Bond et al., 2013). Previous climate modeling studies simulate annual warming in the Arctic region with the inclusion of BC in snow (Flanner et al., 2007, 2009; 
Hansen and Nazarenko, 2004; Hansen et al., 2005; Jacobson, 2004) and find BC-snow forcing induces a global temperature response about 3 times greater than equal forcing from $\mathrm{CO}_{2}$ (Flanner et al., 2007). BC influences snow coverage by warming the atmosphere, reducing surface insolation through "dimming", and reducing snow reflectance through darkening caused by BC deposition to snow surface. Globally, the darkening effect within snow increases solar heating of snowpack and exceeds the loss of absorbed energy from dimming, causing a positive net surface forcing and snowpack melting (Flanner et al., 2009). Melting snow also tends to retain $\mathrm{BC}$ aerosols, which darken the surface more and increase absorption of insolation (e.g., Doherty et al., 2013). Therefore, it is important for coupled aerosol-climate and ice sheet models to include $\mathrm{BC}$ darkening effects, and yet most do not.

Global BC emissions from fossil fuel and biofuel combustion have increased dramatically during the industrial era. Since the early 20th century, BC emissions also shifted spatially, decreasing in North America and Europe but increasing in Asia (Bond et al., 2007, 2013). Both the spatial pattern of emissions and the circulation features that are coincident with emissions can strongly affect the amount of $\mathrm{BC}$ reaching the Arctic and depositing to the GrIS (Doherty et al., 2010; Thomas et al., 2017; Jiao et al., 2014).

In this study, we develop a BC deposition-snowmelt kernel using the Community Earth System Model (CESM) to investigate changes in snowmelt and surface runoff due to variations in the amount and timing of aerosol deposition on the GrIS. More than 5000 simulations are conducted with the Community Land Model (CLM) component of CESM, driven with a large range of wet and dry BC deposition fluxes to determine relationships between snowmelt perturbation and deposition amount occurring in different months. The final kernel product is resolved by type of BC deposition (wet or dry), deposition amount, deposition month, and deposition year ranging from 2006 to 2015 . It is our hope that this kernel will benefit regional and global aerosol modeling communities by allowing them to estimate GrIS snowmelt and surface runoff perturbations associated with different aerosol deposition fluxes.

\section{Methods}

\subsection{Simulation design}

We use the CESM version 1.2.2 and run the offline CLM (Oleson et al., 2013) version 4.5 with prescribed wet or dry $\mathrm{BC}$ deposition in the snow sub-model to study the effects of $\mathrm{BC}$ deposition on snowmelt and runoff from Greenland. Our motivation for using CLM in this offline configuration is that (1) it reduces noise associated with ocean and atmosphere variability, enabling clearer identification of the runoff signal caused by snow perturbations, and (2) the simulations are computationally cheap, allowing us to explore a large parameter space. We drive the simulations using meteorological forcing data from the Climatic Research Unit and National Centers for Environmental Prediction (CRUNCEP) (Viovy, 2012) over the period of 2006-2016. CRUNCEP data cover the global land surface at a spatial resolution of a $0.5^{\circ} \times 0.5^{\circ}$ and are provided with relatively low latency, allowing us to explore conditions over the recent past. In CLM, the representation of terrestrial snow, including over ice sheets, is based loosely on the SNTHERM model (Jordan, 1991) and is described in detail by Oleson et al. (2013). Snow albedo and solar absorption within each snow layer are simulated with the Snow, Ice, and Aerosol Radiation (SNICAR) model, which accounts for solar zenith angle, albedo of the substrate underlying snow, mass concentrations of LAI (black carbon, dust, organic carbon, and volcanic ash), and ice effective grain size. In general, CLM/SNICAR represents five vertical snow layers and accounts for variations in LAI concentration due to dry and wet deposition, particle flushing and retention with meltwater, snow sublimation, and layer combinations and divisions (Oleson et al., 2013). Dry BC deposition from the atmosphere occurs through gravitational settling and turbulent mixing, primarily transferring hydrophobic $\mathrm{BC}$ to the surface, while wet $\mathrm{BC}$ deposition occurs via precipitation and only affects hydrophilic BC in the model. CLM maintains mass burdens of both hydrophilic BC and hydrophobic $\mathrm{BC}$ within each snow layer, with each species having unique optical properties and meltwater removal efficiencies. Deposited particles are assumed to be instantly mixed and homogeneous within the surface snow layer, which does not exceed $2 \mathrm{~cm}$ in thickness. The particles are added after the computation of interlayer water fluxes, thus preventing particles in the top layer from being washed out immediately before radiative calculations. Particle masses are redistributed vertically in each time step proportionately with snowmelt through the snow column, scaled by the species-specific melt scavenging efficiency and snow layer combination and subdivision. The masses carried out with meltwater drainage through the bottom snow layer are permanently lost from the snowpack and are not maintained within the model (Oleson et al., 2013).

For each simulation used to generate the kernel relating melt runoff to $\mathrm{BC}$ deposition, we prescribe uniform concentrations of $\mathrm{BC}$ within precipitation or uniform dry deposition fluxes over the ice sheet for a period of 1 month, and quantify perturbations to snow and melt runoff for 1 year or more following the period of deposition. A total of 23 unique $\mathrm{BC}$ concentrations in precipitation (e.g., snow) are prescribed to provide wet $\mathrm{BC}$ flux in the CLM. We use a wide range of wet $\mathrm{BC}$ concentrations (from 1 to $500 \mathrm{ng} \mathrm{g}^{-1}$ ) with $\log$ arithmic spacing, aiming to cover historically observed $\mathrm{BC}$ concentrations over the Greenland region (Fig. 1) and potential severe episodes associated with extreme fire activity. For example, measured values of $\mathrm{BC}$ in Greenland snow during 2012-2014, collected from snow pits across a long tran- 


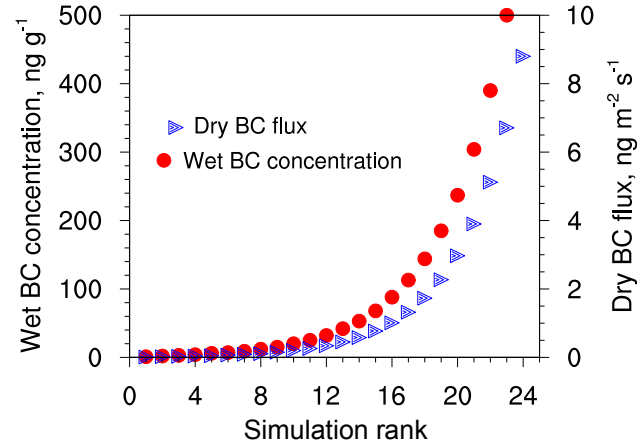

Figure 1. Prescribed values of $\mathrm{BC}$ concentrations in precipitation (red) and dry deposition fluxes (blue) applied in the CESM modeling studies. Spacing between values is logarithmic.

sect, averaged $2.6 \mathrm{ng} \mathrm{g}^{-1}$ (Polashenski et al., 2015). Peak values throughout the depth of the snow pits averaged 4 and $15 \mathrm{ng} \mathrm{g}^{-1}$ in 2012 and 2013, respectively, and the largest single measurement was $43 \mathrm{ng} \mathrm{g}^{-1}$. Ice core measurements from D4 dating back to 1788 show annual-mean concentrations peaking in the early 20 th century at $\sim 12.5 \mathrm{ng} \mathrm{g}^{-1}$, mean concentrations of $2.3 \mathrm{ng} \mathrm{g}^{-1}$ during 1952-2002, and occasional monthly-mean peaks exceeding $50 \mathrm{ng} \mathrm{g}^{-1}$ due to biomass burning events (McConnell et al., 2007). Correspondingly, the maximum dry $\mathrm{BC}$ deposition flux is calculated as the product of the maximum wet $\mathrm{BC}$ concentration $\left(500 \mathrm{ng} \mathrm{g}^{-1}\right)$ and the mean monthly snowfall $\left(1.75 \times 10^{-5} \mathrm{~mm} \mathrm{~s}^{-1}\right)$ over an 11-year (2006-2016) CESM simulation. We prescribe 24 unique dry BC fluxes $\left(0.01-8.80 \mathrm{ng} \mathrm{m}^{-2} \mathrm{~s}^{-1}\right)$ with logarithmic spacing in our study (Fig. 1).

With each prescribed $\mathrm{BC}$ deposition value, we perform 12 simulations with specified BC deposition month from January to December in each deposition year. Each simulation starts from January in the deposition year and extends to 1 full year after the deposition month in order to study the annually integrated BC effects. We then repeat these simulations for 10 years (2006-2015) to generate a climatological product and explore the magnitude of interannual variability in melt perturbations due, for example, to differences in precipitation and near-surface air temperatures. In summary, we perform 2760 simulations ( 23 wet $\mathrm{BC}$ concentrations $\times 12$ deposition months $\times 10$ deposition years) to study the effects of wet BC deposition, and 2880 simulations ( 24 dry $\mathrm{BC}$ fluxes $\times 12$ deposition months $\times 10$ deposition years) to study the effects of dry BC deposition. A total of 120 simulations (12 deposition months $\times 10$ deposition years) without $\mathrm{BC}$ deposition are also performed as parallel control/base runs from which to derive the perturbations induced by $\mathrm{BC}$ deposition. The time step of CLM/SNICAR for our simulations is $0.5 \mathrm{~h}$, and the spatial resolution is $0.9^{\circ} \times 1.25^{\circ}$. The kernel product is calculated as monthly mean values with the same spatial resolution.



Figure 2. The 10-year (2006-2015) averaged hydrophilic BC concentration associated with wet deposition $(\mathbf{a}, \mathbf{b}, \mathbf{e}, \mathbf{f})$ and hydrophobic $\mathrm{BC}$ concentration associated with dry deposition $(\mathbf{c}, \mathbf{d}, \mathbf{g}, \mathbf{h})$ in the top snow layer. The contour maps show concentrations caused by January deposition (a-d) and June deposition (e-h), associated with the maximum wet and dry deposition scenarios depicted in Fig. 1.

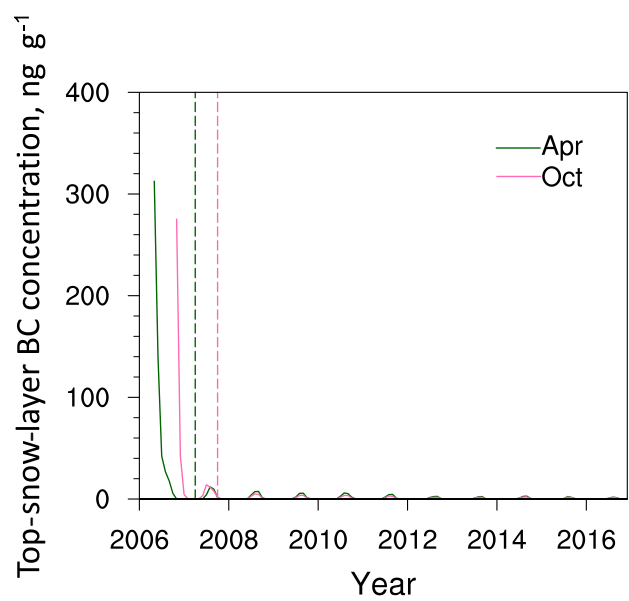

Figure 3. Temporal evolution of hydrophilic BC concentration in the top snow layer averaged over the Greenland region from two 11-year (2006-2016) simulations with wet BC deposition occurring in April and October of the first year. The $\mathrm{BC}$ concentration in precipitation is the maximum value shown in Fig. 1. Dashed lines represent the ends of 1 year since different deposition months.

\subsection{Simulation length evaluation based on top-snow layer BC concentration}

To evaluate the importance of simulation length for the purposes outlined, we focus on $\mathrm{BC}$ concentration in the top snow 
layer because properties of this layer dominate the bulk solar radiative properties of the snowpack. In Fig. 2, we examine the mean distribution of BC concentration in the top snow layer over Greenland after maximum wet and dry BC deposition fluxes occur in January and June. These contours are averaged over 10 years to show a climatological state. Top-layer BC concentrations after wet BC deposition show higher values in the center and south margins of Greenland (Fig. 2a, b, e, f), which matches the general precipitation pattern over the GrIS, with elevated precipitation amount in the center and south of the GrIS. Meanwhile, higher toplayer BC values occur over the north of Greenland after dry BC deposition (Fig. 2c, d, g, h), as lower precipitation in these regions enhances the effect of dry deposition. Also, we find lower concentrations induced by the maximum wet BC (Fig. 2a, b, e, f) than by the maximum dry BC deposition (Fig. 2c, d, g, h). Top-layer BC concentration decreases rapidly only 1 month after the deposition month for both winter and summer deposition (i.e., from January to February with January deposition in Fig. 2a-d, and from June to July with June deposition in Fig. 2e-h) as new snowfall dilutes the contaminated snow. The rapid decrease in BC concentration supports the notion that a 1-year simulation length should capture most of the time-integrated effect from a deposition event. To verify this, we also perform two 11-year (20062016) simulations with the maximum wet BC deposition occurring in April and October of the first year to evaluate the long-term variation in top-layer $\mathrm{BC}$ concentration. In these long-term simulations, we find top-layer BC concentrations decrease rapidly within a 1-year period after both spring and fall depositions (Fig. 3). We also see, however, that residual $\mathrm{BC}$ reappears at the surface in subsequent summers because of snow melting and associated accumulation of impurities at the top of the snowpack (Doherty et al., 2013). In the model, this occurs because melt scavenging ratios for both types of $\mathrm{BC}$ are less than 1 , meaning that proportionately less $\mathrm{BC}$ moves down vertically in the column than meltwater. As we will see, summer reappearance of impurities at the snow top has a non-negligible impact on the annually integrated runoff perturbation, but the peaks in subsequent years are less than $1 / 20$ of the $\mathrm{BC}$ concentrations in the deposition month, indicating that the 1-year simulation setup is reasonable to capture the major portion of the total BC influences.

\section{Results and discussion}

Deposited BC to snow causes a darkening effect and enhances snowmelt and Greenland runoff. Here, we first show variations in top-snow-layer BC concentrations and then examine total GrIS runoff perturbation induced by BC deposition.

\subsection{BC concentration in the top snow layer}

We investigate the climatological (i.e., averaged over 10 simulations covering 2006-2015) 1-year evolution of top-snowlayer BC concentration averaged over Greenland for different deposition months. Figure 4 depicts the temporal evolution of top-layer $\mathrm{BC}$ concentration for the maximum wet and dry BC fluxes from our matrix of simulations. For all months of deposition, top-layer concentrations decrease rapidly as fresh snow covers the contaminated surface. Top-snow layer concentrations of dry-deposited BC generally decrease more slowly than those of wet-deposited BC. One reason for this behavior during summer months is that dry-deposited BC is assumed to be hydrophobic and have a lower meltwater scavenging efficiency, reducing the rate at which it is carried away by melting water. We also see, however, that some winter-deposited BC can persist in the top layer until, or even reappear during, the summer melt season, indicating that $\mathrm{BC}$ deposition in non-melting seasons can also be important for GrIS melting. Reexposure of previously deposited BC occurs as overlying snow melts and flushes through the snow, removing some but not all of the underlying impurities and eventually exposing the dirty snow layer at the surface.

We also investigate how top-layer BC concentration varies with different $\mathrm{BC}$ deposition values and how this variation evolves over 1 year following deposition (Figs. 5, 6). For all deposition months, top-snow layer BC concentration increases, as expected, with increasing $\mathrm{BC}$ deposition flux. The relationship between top-layer $\mathrm{BC}$ concentration and the $\mathrm{BC}$ deposition value is nearly linear, although we find indications of saturation at later times with dry BC deposition (e.g., as in Fig. 6h-1). Figure 7 summarizes top-layer BC concentration variation with deposition amount at different times $(0$ 11 months since deposition) averaged over all the deposition months. With this averaging, we find that top-layer BC concentrations decrease monotonically from month 0 to month 11. Again, we find slower decrease in the dry deposition simulations than in the wet deposition simulations. With wet BC deposition, the rate of decrease slows down after 3-6 months, which could be due to the summer peaks resulting from snow melting and BC integration (Fig. 4).

\subsection{Temporal variation in GrIS total runoff}

We define total runoff in CLM as the summation of surface runoff, subsurface drainage, and runoff from glacier surface. We first examine the seasonal and interannual variation in GrIS total runoff, integrated over the entire GrIS, in the base run without BC deposition (Fig. 8). Total runoff shows clear summer peaks and some interannual variation. Annualintegrated total runoff is $\sim 120 \mathrm{Gt} \mathrm{yr}^{-1}$, with the highest value of $\sim 140 \mathrm{Gt}$ in 2014 (Fig. 8b). Compared with satellite gravity measurements during 2005-2010 showing Greenland is losing mass at a rate of $\sim 229 \mathrm{Gt} \mathrm{yr}^{-1}\left(169-290 \mathrm{Gt} \mathrm{yr}^{-1}\right)$, of which $50 \%-70 \%$ is lost through surface melt (Vaughan 

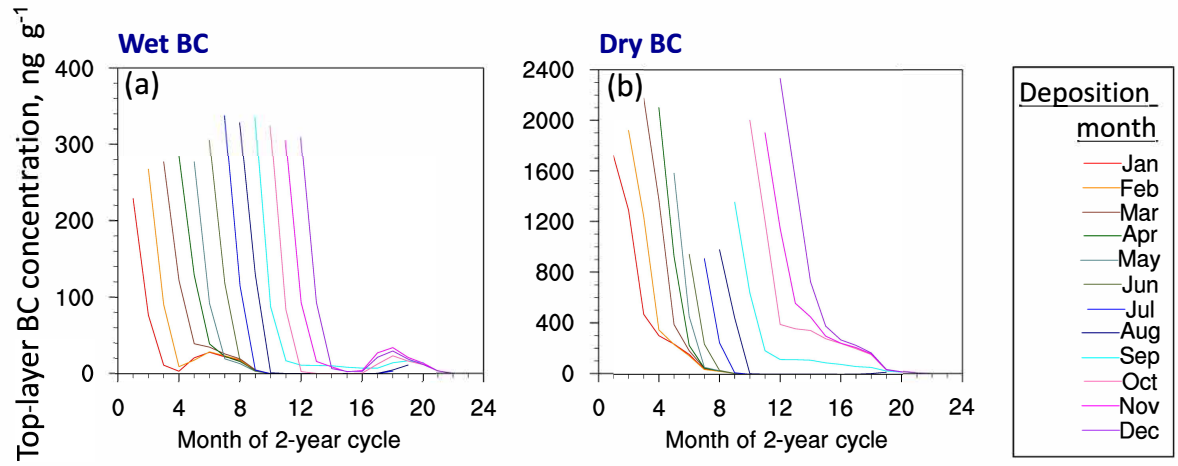

Figure 4. Temporal evolution of hydrophilic BC concentration (a) and hydrophobic BC concentration (b) in the top snow layer averaged over the Greenland region from the simulations with the maximum wet and dry BC deposition, respectively. Each line starts from the BC deposition month, extends 1 year, and represents the mean time series from 10 simulations that start in each year from 2006 to 2015 .
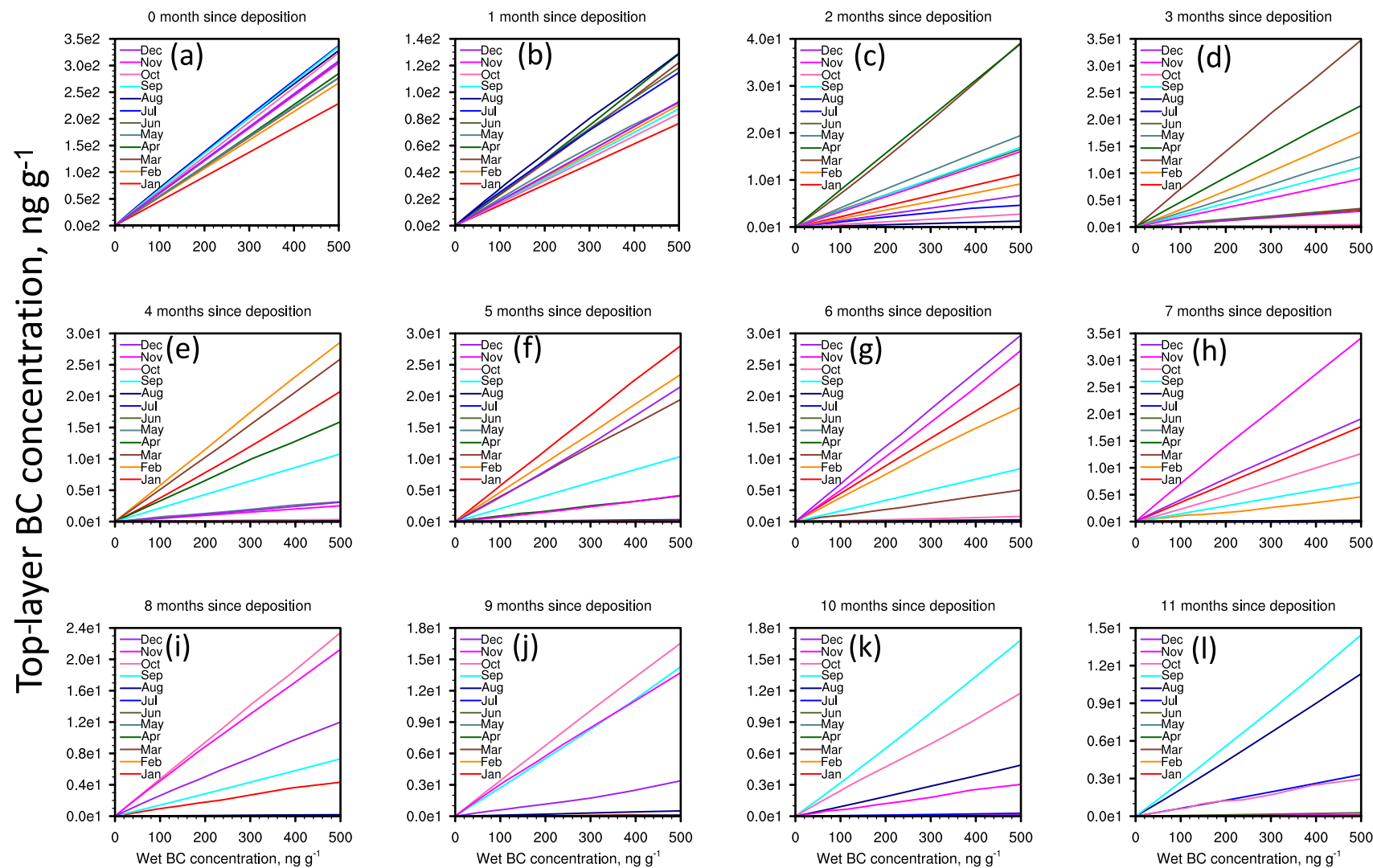

Figure 5. Hydrophilic BC concentration in the top snow layer vs. concentration of BC in precipitation shown at different times (0-11 months, panels a-l) since deposition. The top-snow-layer concentrations are averaged over the Greenland region and over 101 -year simulations beginning in the years 2006-2015. Different line colors represent different deposition months.

et al., 2013), the simulated total runoff in the base run in our study is within a reasonable range.

We then calculate perturbed total runoff due to BC deposition as the difference in runoff between simulations with $\mathrm{BC}$ deposition and paired base simulations without $\mathrm{BC}$ deposition. We select three wet $\mathrm{BC}$ deposition values and three dry
$\mathrm{BC}$ deposition values to illustrate the seasonal and interannual variations in perturbed total runoff (Fig. 9). We note that different scales are used in the panels of Fig. 9, which shows that higher deposition causes more total runoff. We also find clear interannual variations for different deposition amounts and months. The variations in perturbed total runoff in Fig. 9 

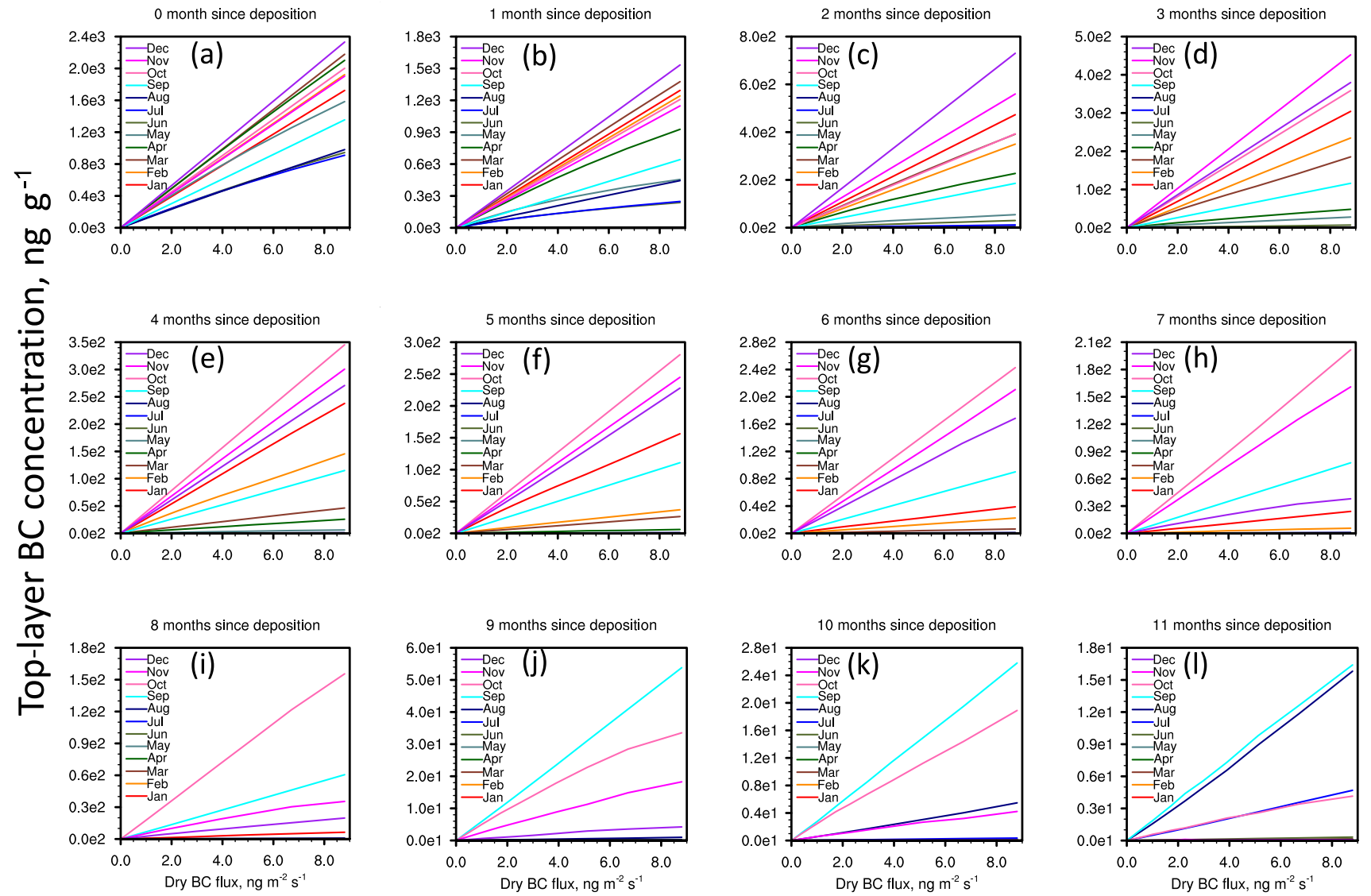

Figure 6. Same as Fig. 5, but showing hydrophobic BC concentration in the top snow layer vs. BC dry deposition flux.
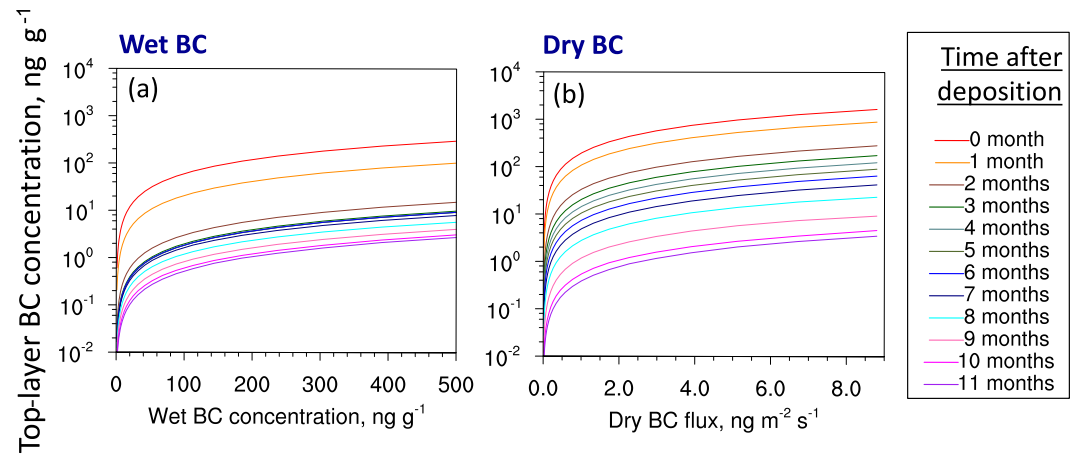

Figure 7. Hydrophilic BC concentration in the top snow layer vs. concentration of BC in precipitation (a), and hydrophobic BC concentration in the top snow layer vs. BC dry deposition flux (b) shown at different times (0-11 months) since deposition. The top-snow-layer concentrations are averaged over the Greenland region, over all the deposition months, and over 10 1-year simulations beginning in the years 2006-2015.

follow the variation in total runoff in the base run (Fig. 8) in general, especially for the perturbed simulations with wet $\mathrm{BC}$ depositions, indicating that $\mathrm{BC}$ deposition could have a greater effect in warmer years, when more of the ice sheet is near the melting temperature. This could also be due to an amplification effect by metamorphism of snow in warmer years.
To remove the effect of yearly variation, we also investigate the climatological (i.e., averaged over 10 simulations spanning 2006-2015) 1-year evolution of total runoff increase due to $\mathrm{BC}$ deposition starting from different deposition months. Again, we examine total runoff increase induced by maximum wet and dry $\mathrm{BC}$ depositions to understand general behavior associated with very large perturba- 

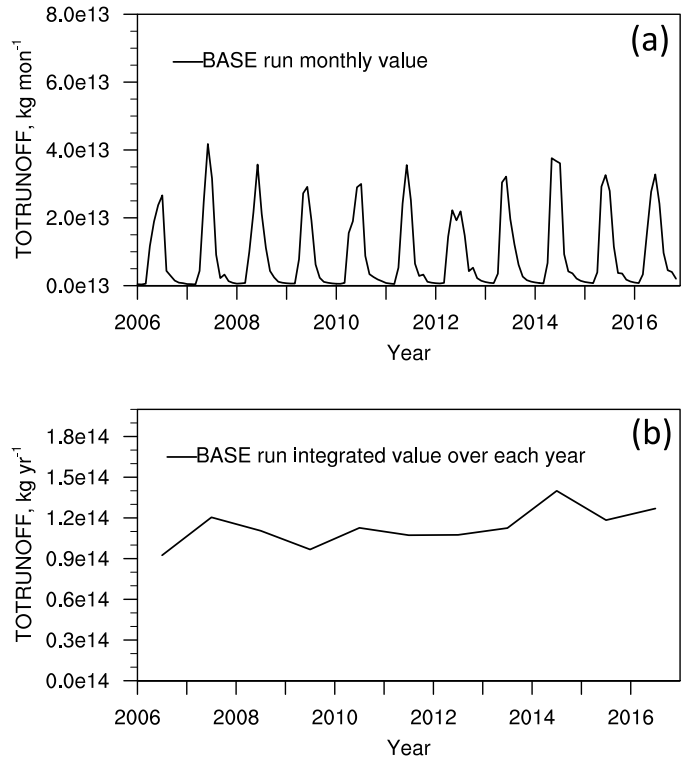

Figure 8. Monthly (a) and annually integrated (b) time series of total runoff from Greenland in the base run without BC deposition.

tions, for which the signal is much larger than noise. As shown in Fig. 10, we find two summer peaks of total runoff increase, with the second peak caused by the reexposure of $\mathrm{BC}$ during the summer after deposition. We also find total runoff perturbation is the largest in July for all months of deposition, followed by August. The largest perturbation in summer could be caused by immediate melting due to darkening, as well as larger grain size in a warmer environment.

\subsection{GrIS total runoff variation with deposition amount}

As represented by Fig. 9, a higher deposition amount causes a larger total runoff increase. Here, we examine total runoff perturbation caused by all deposition amounts and how total runoff distributes over Greenland. Figures 11 and 12 show climatological mean (2006-2015) annually integrated total runoff increase caused by June BC deposition via wet and dry processes, respectively. June deposition is selected for these figures because of its high potential to impact summer melt. Although BC is well distributed over the whole GrIS (Fig. 2), total runoff perturbations are largely confined to the low-elevation margins with both wet and dry BC deposition (Figs. 11, 12), as these remain the only areas warm enough in the model simulations for substantial melt to occur, which is consistent with the Tedesco (2007) study. We note that the spatial distribution of model melt will be sensitive to surface air temperature and insolation, the latter of which can vary substantially among reanalysis products. Runoff effects of dry BC deposition show patterns similar to those of impacts from $\mathrm{BC}$ in precipitation. We find that small fluxes of $\mathrm{BC}$ via dry deposition are not as effective as similar deposition fluxes of $\mathrm{BC}$ in precipitation, and we attribute this to the higher light absorptivity (and hence radiative forcing per unit mass) of hydrophilic BC than of hydrophobic BC. The former is assumed to be coated with nonabsorbent sulfate and hence its mass absorption cross section is about $50 \%$ larger than that of uncoated hydrophobic BC (Flanner et al., 2007).

Figure 13 summarizes the variation in total runoff perturbation versus deposition amount for different deposition months. The maximum $\mathrm{BC}$ deposition perturbs total runoff by up to $\sim 20 \%(24 \mathrm{Gt})$ in the wet BC deposition simulations, although we note that continent-wide fluxes of this magnitude (500 $\mathrm{ng} \mathrm{g}^{-1}$ in precipitation) are much larger than ever observed on Greenland. With a modest deposition concentration (e.g., $5 \mathrm{ng} \mathrm{g}^{-1}$ ), the runoff perturbation is $\sim 0.4 \%$ $(\sim 0.5 \mathrm{Gt})$. Different deposition months cause annually integrated total runoff perturbation to vary by $40 \%-60 \%$ (12 $\mathrm{Gt} \mathrm{yr}^{-1}$ in the maximum $\mathrm{BC}$ deposition case). Also, we find $\mathrm{BC}$ deposition in June and July induces the largest annually integrated total runoff increase. To further verify the most influential deposition month, we select five wet BC and five dry $\mathrm{BC}$ deposition values and plot total runoff increase versus deposition month, shown in Fig. 14. Figure 14a shows annual integrated total runoff from the base run, starting from different months, serving as a reference for the perturbations shown in Fig. 14b-f. For different deposition amounts from low to high (Fig. 14b-f), BC deposition in summer (i.e., June, July, and August) causes the highest annual total runoff increase. With higher deposition (Fig. 14e-f), June deposition generates the largest annual total runoff for both dry and wet BC deposition, whereas with lower deposition amounts the month of maximum impact can be June or July. As noted earlier, however, deposition during non-summer months also causes substantial melt and runoff perturbations, owing to the melt-induced resurfacing of impurities during summer in the ablation zone.

\section{Evaluation and application of the kernel product}

We turn now to evaluating the kernel product and advising a straightforward way in which it can be applied to realistic aerosol deposition fluxes. We perform 10 1-year CLM simulations with spatially and temporally varying wet or dry BC deposition fluxes occurring in randomly selected years and months, and we evaluate the accuracy of the kernel product using total GrIS BC deposition amount and total runoff from these new simulations (the "evaluating simulations"), compared with total runoff from the kernel for equivalent deposition fluxes. The evaluating simulations use prescribed wet and dry BC deposition fields that were generated from a global aerosol run with CAM (Lamarque et al., 2010). In different evaluating simulations, the prescribed $\mathrm{BC}$ deposition fields are multiplied by factors ranging from 2 to 50 for wet $\mathrm{BC}$ deposition and from 2000 to 20000 for dry BC deposition to provide different $\mathrm{BC}$ deposition amounts within the range of wet or dry deposition in the kernel. High scaling 


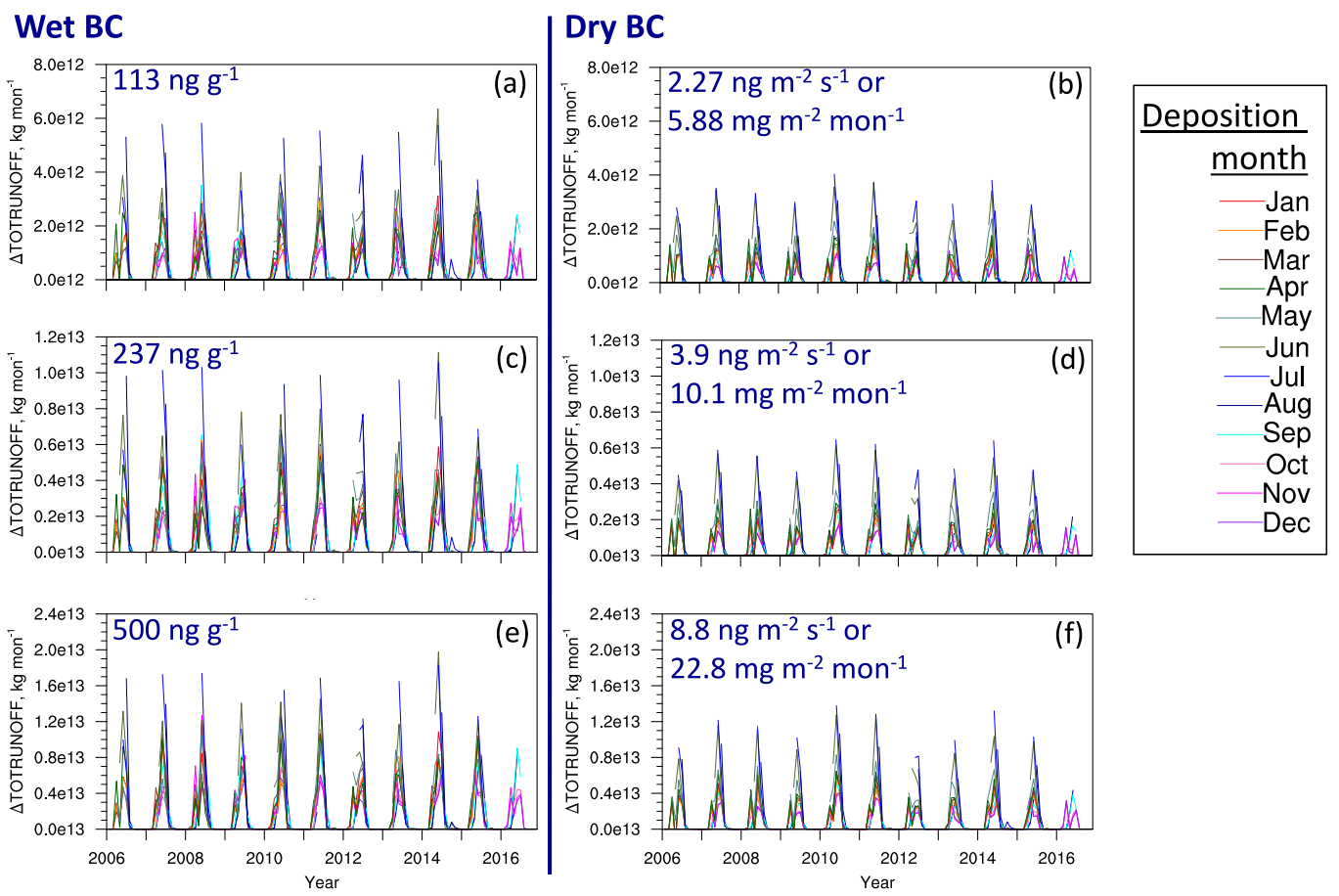

Figure 9. Monthly time series of the increase in total Greenland runoff resulting from BC deposition. Values of BC concentrations in precipitation $(\mathbf{a}, \mathbf{c}, \mathbf{e})$ and dry deposition fluxes $(\mathbf{b}, \mathbf{d}, \mathbf{f})$ are shown in each plot. Each line starts from the BC deposition month and extends 1 year. Different line colors represent different deposition months.
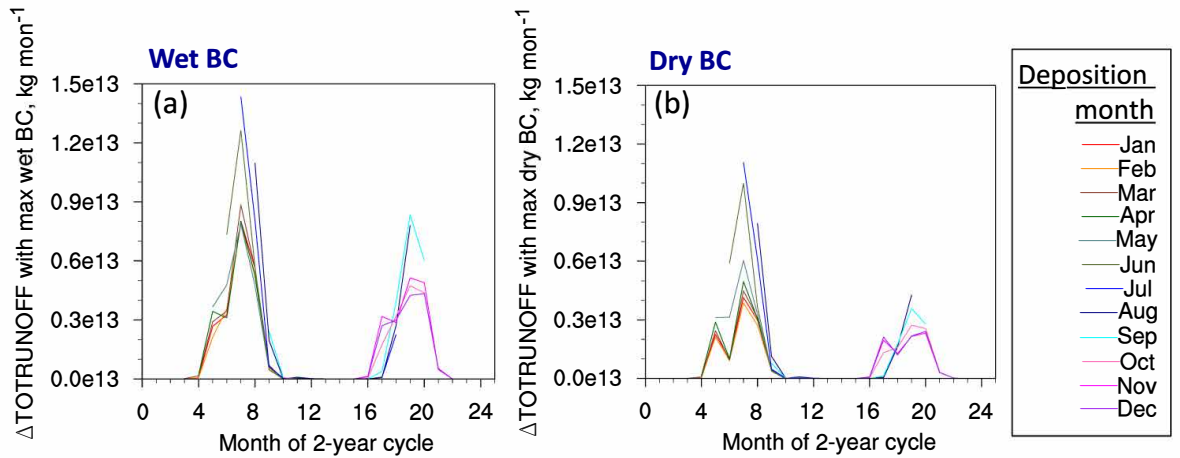

Figure 10. Temporal evolution of 10-year (2006-2015) averaged total runoff increase resulting from BC deposition, summed over the entire Greenland region from the simulations with the maximum wet (a) and dry (b) BC deposition. Each line starts from the BC deposition month and extends 1 year.

factors are applied to dry-hydrophobic BC deposition simulations because the prescribed dry $\mathrm{BC}$ deposition from CAM is very low and within the noise regime. We also perform two 10-year (2006-2015) evaluating simulations with both CAM prescribed wet and dry $\mathrm{BC}$ deposition fluxes turned on throughout the whole simulations to examine short-term, long-term, and climatological 1-year integrated total runoff effects. BC deposition fluxes in one of the 10-year evaluating simulations are multiplied by a factor of 5 to provide a high-deposition event and are left at unperturbed (i.e., realistic) values in the other simulation. Also, different deposition years and months indicate different $\mathrm{BC}$ distributions. Therefore, the evaluating simulations provide a variety of scenarios with distinct $\mathrm{BC}$ deposition amounts and distributions to evaluate performance of the kernel.

Figure 15 shows maximum, mean, and minimum 1-year integrated total runoff increase versus BC deposition amount from the kernel product, with results from the evaluating simulations overlaid on the kernel lines. With varying BC deposition amount and distribution, including combined wet and dry BC deposition fluxes, results from the evaluating simulations are mostly within the total runoff ranges of our ker- 


\section{0-year average of 12-month integrated $\triangle T O T R U N O F F$ since deposition in Jun}
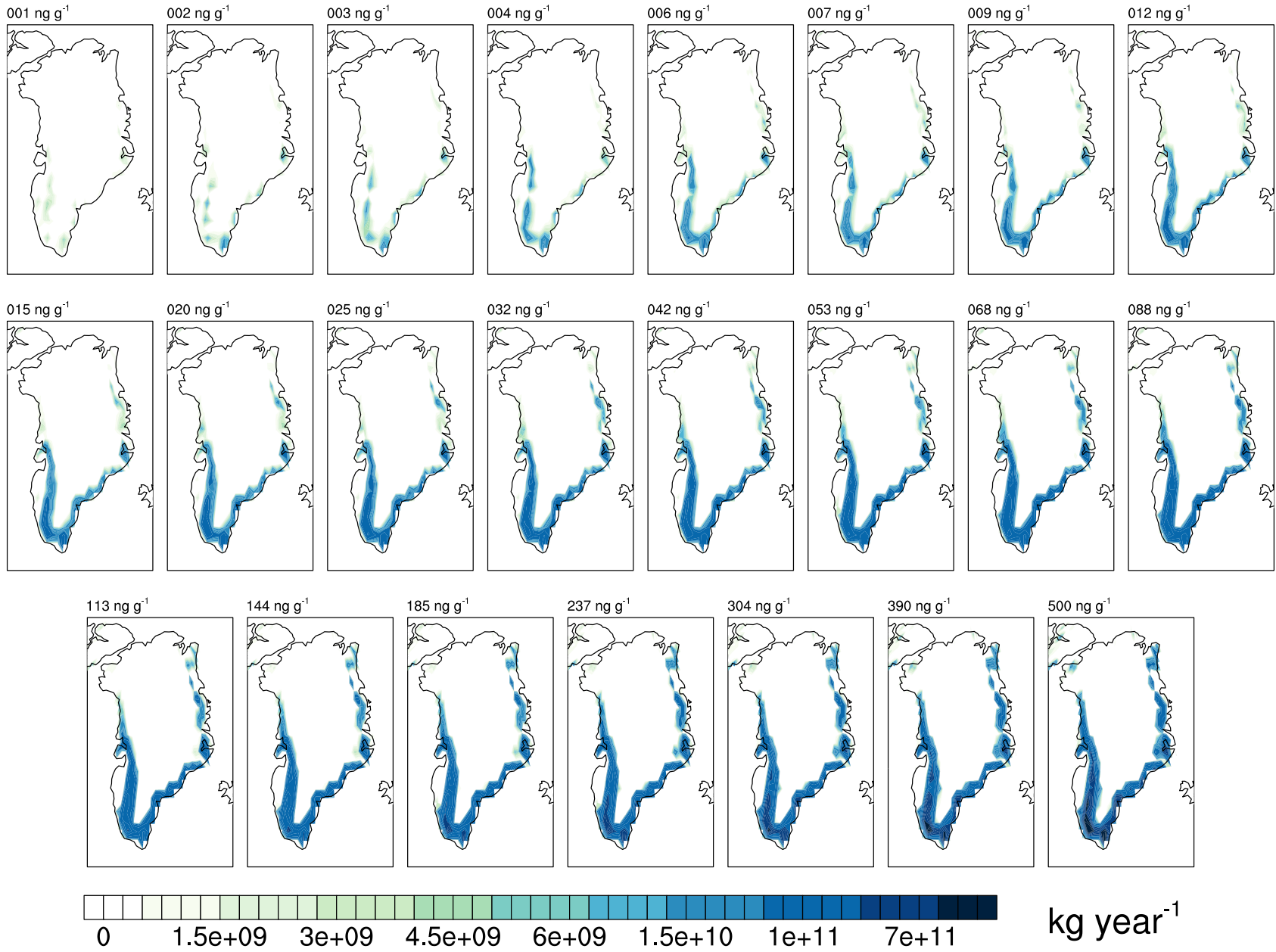

Figure 11. The 10-year average of annually integrated total runoff increase resulting from different concentrations of BC in precipitation, deposited only during June. The average is over 10 1-year simulations starting in each year from 2006 to 2015.

nel product for both wet and dry $\mathrm{BC}$ deposition. In the evaluating simulations with combined wet and dry BC depositions, hydrophobic BC fluxes are very low $(<1 / 100$ of wet $\mathrm{BC}$ fluxes); therefore, we treat all $\mathrm{BC}$ deposition as wethydrophilic BC and overlay the results on the wet deposition curves. We note CAM-simulated BC deposition from the one time-evaluating run is comparable with measured values of BC in Greenland snow and ice core measurements (Polashenski et al., 2015; McConnell et al., 2007). The increases of 1-year-integrated total runoff from the 10-year-evaluating simulations with realistic deposition exhibit wide ranges, for example, with a minimum of $\sim 4 \mathrm{Gt}$ in the first deposition year (2006) to a maximum of $\sim 10 \mathrm{Gt}$, and with a minimum of $\sim 14 \mathrm{Gt}$ in the first year to a maximum of $\sim 40 \mathrm{Gt}$ in the simulation with $\mathrm{BC}$ fluxes that are 5 times bigger. The climatological (i.e., averaged over 10 years) total runoff perturbations ( $\sim 8$ and $\sim 30 \mathrm{Gt} \mathrm{yr}^{-1}$ in the default and simulations
5 times bigger, respectively) caused by prescribed combined wet and dry $\mathrm{BC}$ deposition are about double the first-year total runoff integrations, which is due to continuous monthby-month depositions in the 10-year-evaluating simulations and the long-term effects of the reappearance of residual BC at the surface as described in Sect. 2.2.

Because the mean and maximum kernel curves in Fig. 15 provide estimates of $\mathrm{BC}$-induced total runoff within a reasonable range, we parameterize these curves to provide a simple application of our kernel product. GrIS-wide melt perturbations are relatively linear with $\mathrm{BC}$ deposition amount, with linear fits to the mean kernel curves for wet and dry BC deposition fluxes of, respectively,

$\triangle$ TOTALRUNOFF $=4.498 \times 10^{5} \times \Delta$ wetBC,

$\triangle$ TOTALRUNOFF $=3.062 \times 10^{5} \times \Delta$ dryBC, 


\section{0-year average of 12-month integrated $\triangle$ TOTRUNOFF since deposition in Jun}
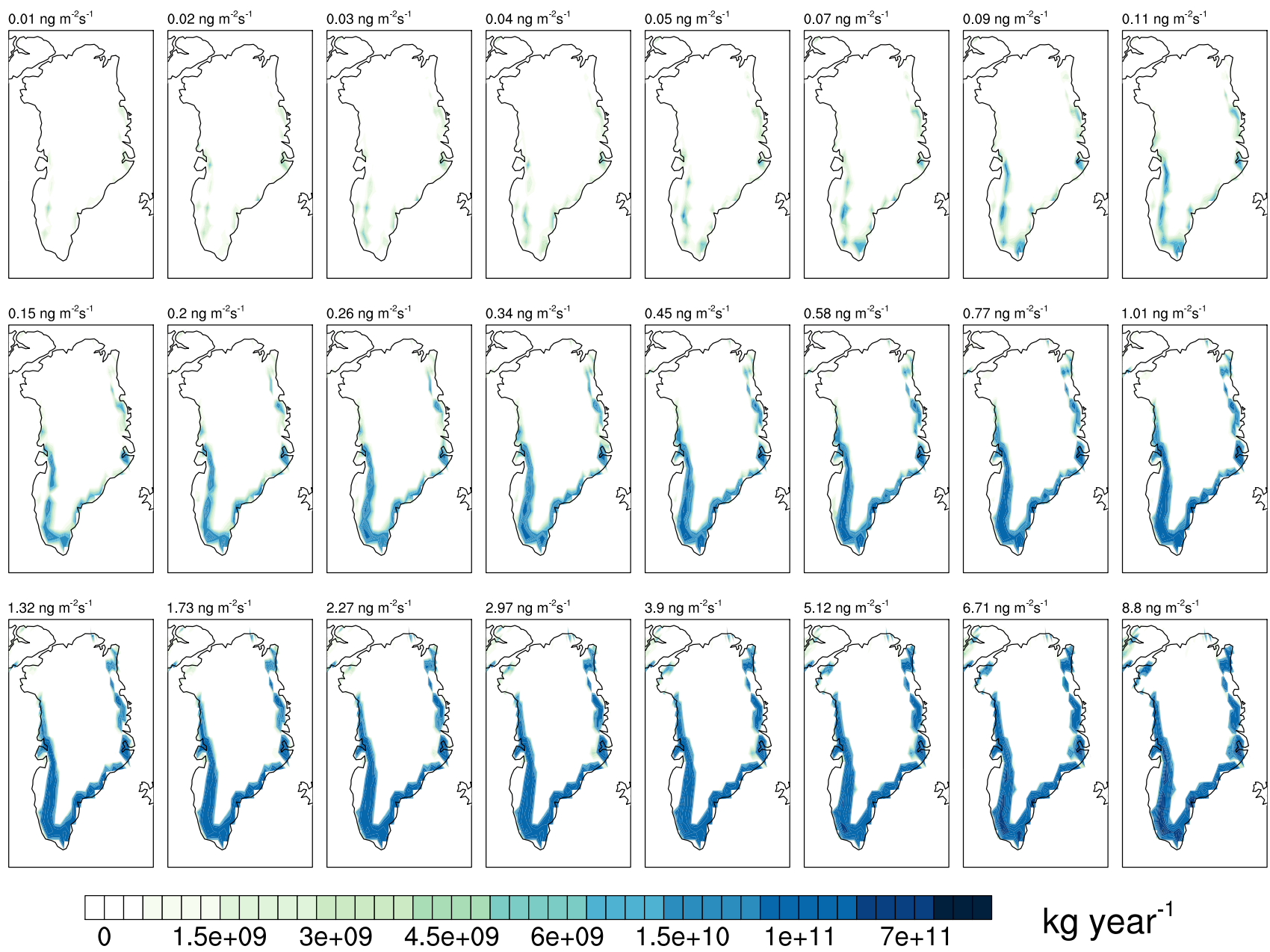

$\mathrm{kg}$ year $^{-1}$

Figure 12. Same as Fig. 11, but resulting from different dry deposition fluxes of BC in June.
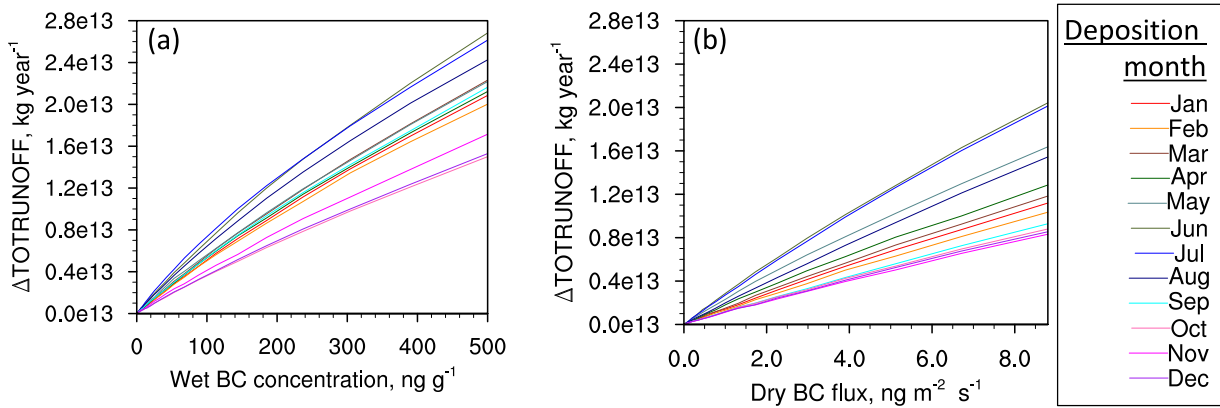

Figure 13. Increase in total Greenland runoff resulting from BC deposition integrated over 1 year starting from the month of BC deposition vs. concentration of BC in precipitation (a) and vs. BC dry deposition flux (b). The runoff values are summed over the Greenland region and averaged over 10 1-year simulations beginning in the years 2006-2015. Different line colors represent different deposition months. 


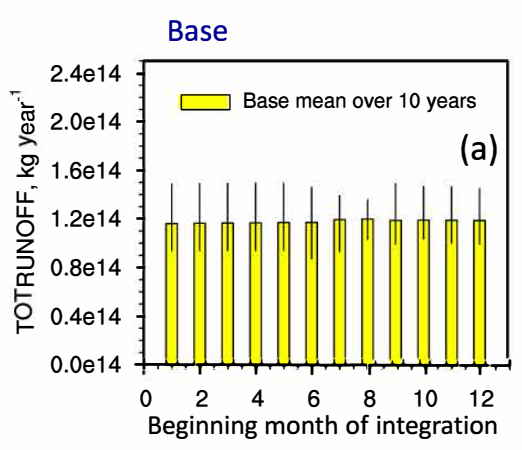

Wet: $113 \mathrm{ng} \mathrm{g}^{-1}$

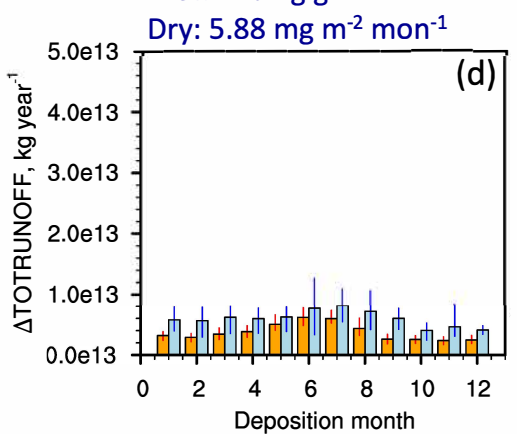

Wet: $25 \mathrm{ng} \mathrm{g}^{-1}$

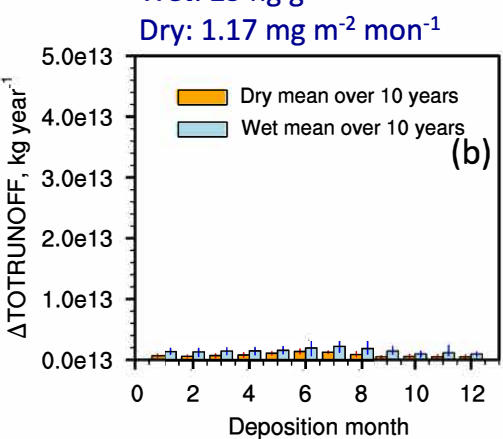

Wet: $237 \mathrm{ng} \mathrm{g}^{-1}$

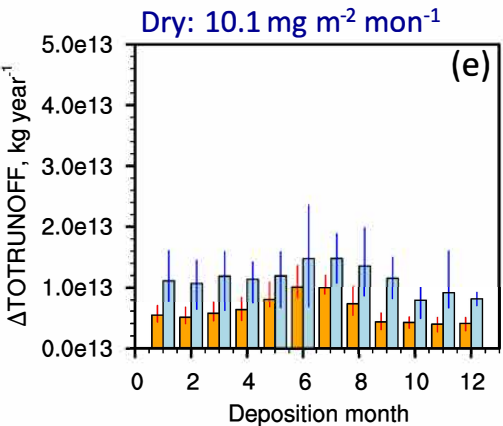

Wet: $53 \mathrm{ng} \mathrm{g}^{-1}$

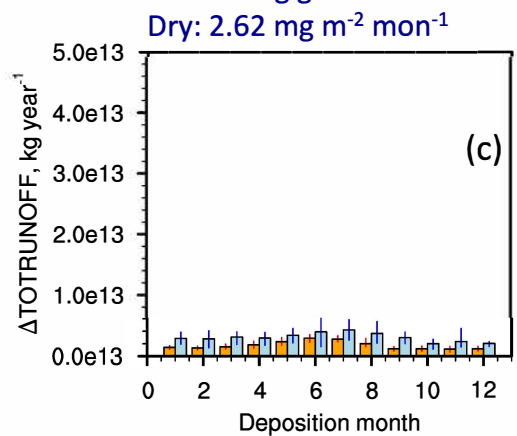

Wet: $500 \mathrm{ng} \mathrm{g}^{-1}$

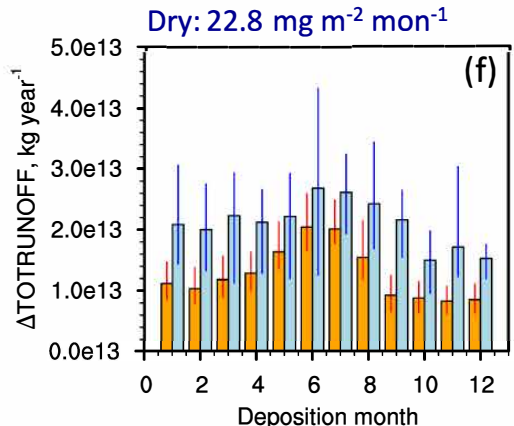

Figure 14. Total runoff in the base run without BC deposition (a) and the increase in total Greenland runoff resulting from BC deposition (b-f), integrated over 1 year starting from the month of BC deposition. The bars show mean values and the whiskers depict the full range of values over all 10 simulations that each start in a different year from 2005 to 2016 . Values of BC concentrations in precipitation and dry deposition fluxes are shown in the title of each plot (b-f).
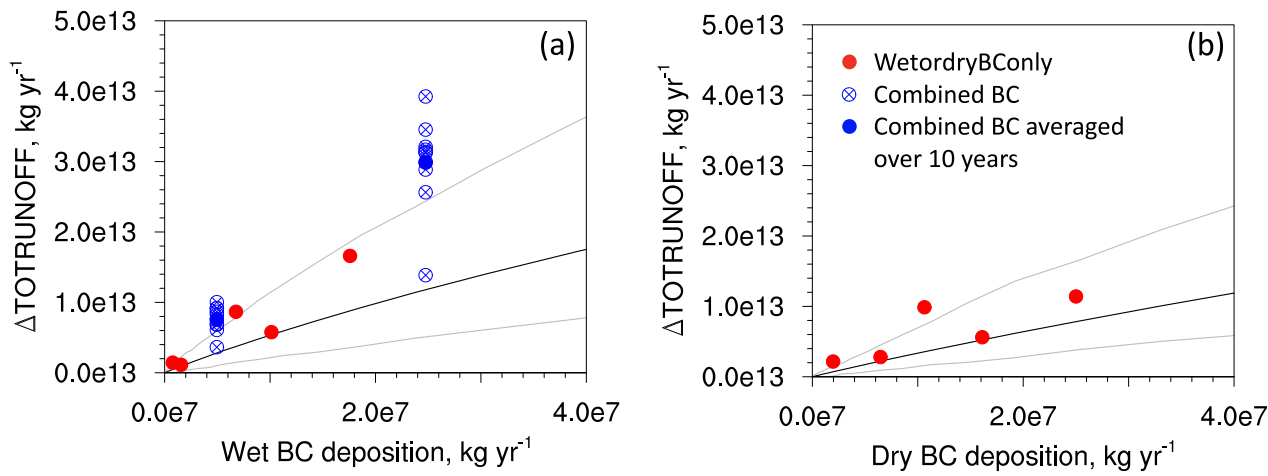

Figure 15. Increase in total Greenland runoff resulting from BC deposition integrated over 1 year starting from the month of BC deposition vs. total wet (a) and dry (b) BC deposition mass flux over the entire GrIS. The runoff values are summed over the Greenland region and averaged over all deposition years and deposition months. Black lines show mean total runoff values, and grey lines show maximum and minimum values from the entire matrix of simulations. Red dots represent explicitly simulated total runoff from the evaluating simulations with prescribed spatially and temporally varying wet or dry BC deposition fluxes in randomly selected months and years. Blue hollow circles represent simulated total runoff from the evaluating simulations with prescribed combined BC deposition fluxes integrated over each year of the 10-year simulations. Blue dots show averages of the hollow circles.

and with linear fits to the maximum kernel curves of

$$
\begin{aligned}
& \Delta \text { TOTALRUNOFF_MAX }=9.322 \times 10^{5} \times \Delta \text { wetBC, } \\
& \Delta \text { TOTALRUNOFF_MAX }=6.348 \times 10^{5} \times \Delta \text { dryBC, }
\end{aligned}
$$

where $\triangle$ TOTALRUNOFF is the mean increase in 1-yearintegrated total runoff $\left(\mathrm{kg} \mathrm{yr}^{-1}\right), \Delta$ TOTALRUNOFF_MAX is the maximum increase in 1-year-integrated total runoff $\left(\mathrm{kg} \mathrm{yr}^{-1}\right)$, and $\triangle$ wetBC and $\triangle$ dryBC are total wet and dry $\mathrm{BC}$ deposition fluxes to the GrIS ( $\left.\mathrm{kg} \mathrm{yr}^{-1}\right)$. Unique relationships for wet and dry deposition arise, again, because of differences in optical properties and melt-induced removal ef- 
ficiencies of hydrophilic and hydrophobic BC. Linearity in the relationship between runoff and $\mathrm{BC}$ deposition is encouraging because we have neglected coincident darkening from other types of LAIs (e.g., dust, algae). In environments where darkening from other LAIs is not too great, the runoff-BC relationships derived here should be valid, though we acknowledge that the incremental effect of $\mathrm{BC}$ will be lower in snow that is heavily laden with other impurities.

The bulk relationships shown above represent the simplest application of our kernel product, allowing a rough estimation of runoff perturbation caused by Greenland-wide wet and dry $\mathrm{BC}$ deposition fluxes. Based on the evaluations in Fig. 15, the mean curves (i.e., Eqs. 1 and 2 from the kernel product) tend to provide a conservative estimate of total runoff, whereas the maximum curves (i.e., Eqs. 3 and 4) represent a more realistic approximation of total runoff induced by $\mathrm{BC}$ deposition that occurs continuously and with varying spatial distribution. Ideally, grid cell-by-grid cell fluxes should be matched to the kernel to account for spatial differences in melt associated with elevation and other conditions (Figs. 11, 12), but at the low end of deposition flux we see considerable noise at the individual pixel and deposition month level, especially for wet deposition fluxes that can be subject to anomalies associated with low precipitation amounts in a given month. To ameliorate this, for typical present-day deposition fluxes we recommend matching month-specific but spatially integrated deposition fluxes or concentrations with the associated Greenland-wide kernel values. Given the large uncertainties that exist in the bulk relationships, even as simulated with complex models, simple parameterizations that include large error bounds are justifiable and will facilitate more analyses of the extended impacts of aerosol deposition to the GrIS.

Finally, although this product only includes BC, we suggest that it could be extended to include other LAI species through a simple scaling that accounts for the ratio of massspecific absorption between the species of interest and the $\mathrm{BC}$ explored here. Rationale for this is that radiative forcing and melt perturbation will scale roughly linearly with absorptivity, at least for relatively low and moderate burdens of LAI. The mass-specific visible band absorption cross sections assumed in our study for hydrophilic (via wet deposition) and hydrophobic (via dry deposition) BC are 7.5 and $11.3 \mathrm{~m}^{2} \mathrm{~g}^{-1}$, respectively. The only other species-specific property affecting results from this study is the meltwater scavenging coefficient, which is assumed to be 0.2 for hydrophilic BC and 0.03 for hydrophobic BC (Flanner et al., 2007). Given relatively large uncertainty in this parameter (Doherty et al., 2013; Qian et al., 2014), we suggest applying the hydrophilic (wet deposition) kernel to all hydrophilic species and the hydrophobic (dry deposition) kernel to all hydrophobic species, along with appropriate scaling of optical properties.

\section{Conclusions}

In this study, $\sim 6000$ simulations are performed to investigate annually integrated runoff perturbation from BC deposition on snow. The simulation matrix includes variations in deposition flux, deposition month and year, and nature of the deposition (wet or dry). From this matrix we produce a largeensemble kernel that relates BC deposition fluxes to GrIS runoff perturbations.

In the month after deposition, top-snow-layer BC concentration decreases rapidly due to fresh snow coverage but then increases somewhat in the ablation zone during the following summer due to melt-induced reexposure of the contaminated snow. Accordingly, the total runoff increase induced by BC deposition is substantial for both summer and winter deposition, though with peak impacts associated with June and July deposition. Impacts from winter deposition suggest that winter emissions, associated for example with biomass heating use, should not be neglected as potential contributors to increased summer melt. Also, we find most of the runoff increase occurs along the margins, and especially on the southern margin of Greenland, with little sign of melting in the center of the GrIS where it is rarely warm enough. Interannual variations in total runoff in the base and BC perturbed simulations indicate that $\mathrm{BC}$ deposition can generate more impact in warmer years, when more of the ice surface is near the melting temperature.

In summary, a higher BC deposition amount leads to higher total runoff. We do not find a clear sign of runoff saturation caused by high BC deposition values in our study. Model-generated deposition fluxes associated with realistic BC emissions induce a climatological-mean (2006-2015) GrIS-wide runoff increase of $8 \mathrm{Gt} \mathrm{yr}^{-1}(+6.8 \%$ perturbation), which corresponds to $0.022 \mathrm{~mm} \mathrm{yr}^{-1}$ of global sea level rise. We also suggest simple linear equations that crudely relate GrIS-wide wet and dry BC deposition fluxes to annually integrated runoff perturbation and provide links to the full spatially varying kernel dataset so that users can derive more accurate estimates of melt perturbation (e.g., resolved by seasonal timing) from deposition fluxes. We also suggest that the kernel results can be applied to other LAI species via simple scaling of the mass absorption cross section. Our hope is that these data will extend the utility of state-of-the-art aerosol models.

Data availability. The kernel product from model runs in this paper is available for download at https://github.com/yanglibj/ snowmelt-kernel (Li, 2018). For questions, please contact the corresponding author, Yang Li (University of Michigan; yanglibj@umich.edu) through e-mail. 
Author contributions. YL performed the simulations, carried out the analyses, and wrote the paper. MGF conceived the study and helped revise the paper.

Competing interests. The authors declare that they have no conflict of interest.

Acknowledgements. This research was supported by the Department of Energy (DOE) grant DE-SC0013991.

Edited by: Yves Balkanski

Reviewed by: three anonymous referees

\section{References}

Bond, T. C., Bhardwaj, E., Dong, R., Jogani, R., Jung, S., Roden, C., Streets, D. G., and Trautmann, N. M.: Historical emissions of black and organic carbon aerosol from energy-related combustion, 1850-2000, Global Biogeochem. Cy., 21, GB2018, https://doi.org/10.1029/2006GB002840, 2007.

Bond, T. C., Doherty, S. J., Fahey, D. W., Forster, P. M., Berntsen, T., DeAngelo, B. J., Flanner, M. G., Ghan, S., Kärcher, B., Koch, D., Kinne, S., Kondo, Y., Quinn, P. K., Sarofim, M. C., Schultz, M. G., Schulz, M., Venkataraman, C., Zhang, H., Zhang, S., Bellouin, N., Guttikunda, S. K., Hopke, P. K., Jacobson, M. Z., Kaiser, J. W., Klimont, Z., Lohmann, U., Schwarz, J. P., Shindell, D., Storelvmo, T., Warren, S. G., and Zender, C. S.: Bounding the role of black carbon in the climate system: A scientific assessment, J. Geophys. Res.-Atmos., 118, 5380-5552, https://doi.org/10.1002/jgrd.50171, 2013.

Box, J. E., Fettweis, X., Stroeve, J. C., Tedesco, M., Hall, D. K., and Steffen, K.: Greenland ice sheet albedo feedback: thermodynamics and atmospheric drivers, The Cryosphere, 6, 821-839, https://doi.org/10.5194/tc-6-821-2012, 2012.

Doherty, S. J., Warren, S. G., Grenfell, T. C., Clarke, A. D., and Brandt, R. E.: Light-absorbing impurities in Arctic snow, Atmos. Chem. Phys., 10, 11647-11680, https://doi.org/10.5194/acp-1011647-2010, 2010.

Doherty, S. J., Grenfell, T. C., Forsström, S., Hegg, D. L., Brandt, R. E., and Warren, S. G.: Observed vertical redistribution of black carbon and other insoluble light absorbing particles in melting snow, J. Geophys. Res.-Atmos., 118, 5553-5569, 2013.

Dumont, M., Brun, E., Picard, G., Michou, M., Libois, Q., Petit, J. R., Geyer, M., Morin, S., and Josse, B.: Contribution of light-absorbing impurities in snow to Greenland's darkening since 2009, Nat. Geosci., 7, 509-512, https://doi.org/10.1038/ngeo2180, 2014.

Flanner, M. G., Zender, C. S., Randerson, J. T., and Rasch, P. J.: Present-day climate forcing and response from black carbon in snow, J. Geophys. Res.-Atmos., 112, D11202, https://doi.org/10.1029/2006JD008003, 2007.

Flanner, M. G., Zender, C. S., Hess, P. G., Mahowald, N. M., Painter, T. H., Ramanathan, V., and Rasch, P. J.: Springtime warming and reduced snow cover from carbonaceous particles, Atmos. Chem. Phys., 9, 2481-2497, https://doi.org/10.5194/acp9-2481-2009, 2009.
Hansen, J. and Nazarenko, L.: Soot climate forcing via snow and ice albedos, P. Natl. Acad. Sci. USA, 101, 423-428, 2004.

Hansen, J. E., Sato, M., Ruedy, R., Nazarenko, L., Lacis, A., Schmidt, G., Russell, G., Aleinov, I., Bauer, M., and Bauer, S.: Efficacy of climate forcings, J. Geophys. Res.-Atmos., 110, D18104, https://doi.org/10.1029/2005JD005776, 2005.

Jacobson, M. Z.: Climate response of fossil fuel and biofuel soot, accounting for soot's feedback to snow and sea ice albedo and emissivity, J. Geophys. Res.-Atmos., 9, D21201, https://doi.org/10.1029/2004JD004945, 2004.

Jiao, C., Flanner, M. G., Balkanski, Y., Bauer, S. E., Bellouin, N., Berntsen, T. K., Bian, H., Carslaw, K. S., Chin, M., De Luca, N., Diehl, T., Ghan, S. J., Iversen, T., Kirkevåg, A., Koch, D., Liu, X., Mann, G. W., Penner, J. E., Pitari, G., Schulz, M., Seland, Ø., Skeie, R. B., Steenrod, S. D., Stier, P., Takemura, T., Tsigaridis, K., van Noije, T., Yun, Y., and Zhang, K.: An AeroCom assessment of black carbon in Arctic snow and sea ice, Atmos. Chem. Phys., 14, 2399-2417, https://doi.org/10.5194/acp14-2399-2014, 2014.

Jordan, R.: A one-dimensional temperature model for a snow cover: Technical documentation for Sntherm. 89, Cold regions research and engineering lab, Hanover NH, 1991.

Keegan, K. M., Albert, M. R., McConnell, J. R., and Baker, I.: Climate change and forest fires synergistically drive widespread melt events of the Greenland Ice Sheet, P. Natl. Acad. Sci., 111, 7964-7967, 2014.

Kintisch, E.: Meltdown, in: American Association for the Advancement of Science, 355, 788-791, 2017.

Krabill, W., Hanna, E., Huybrechts, P., Abdalati, W., Cappelen, J., Csatho, B., Frederick, E., Manizade, S., Martin, C., and Sonntag, J.: Greenland ice sheet: increased coastal thinning, Geophys. Res. Lett., 31, https://doi.org/10.1029/2004GL021533, 2004.

Lamarque, J.-F., Bond, T. C., Eyring, V., Granier, C., Heil, A., Klimont, Z., Lee, D., Liousse, C., Mieville, A., Owen, B., Schultz, M. G., Shindell, D., Smith, S. J., Stehfest, E., Van Aardenne, J., Cooper, O. R., Kainuma, M., Mahowald, N., McConnell, J. R., Naik, V., Riahi, K., and van Vuuren, D. P.: Historical (1850-2000) gridded anthropogenic and biomass burning emissions of reactive gases and aerosols: methodology and application, Atmos. Chem. Phys., 10, 7017-7039, https://doi.org/10.5194/acp-10-7017-2010, 2010.

Li, Y.: The ensemble kernel relating gridded snowmelt to BC deposition over the Greenland Ice Sheet, available at: https://github. com/yanglibj/snowmelt-kernel/ last access: October 2018.

McConnell, J. R., Edwards, R., Kok, G. L., Flanner, M. G., Zender, C. S., Saltzman, E. S., Banta, J. R., Pasteris, D. R., Carter, M. M., and Kahl, J. D.: 20th-century industrial black carbon emissions altered arctic climate forcing, Science, 317, 1381-1384, 2007.

Oleson, K., Lawrence, M., Bonan, B., Drewniak, B., Huang, M., Koven, D., Levis, S., Li, F., Riley, J., and Subin, M.: Technical description of version 4.5 of the Community Land Model (CLM), NCAR Technical Note NCAR/TN-503+STR, https://doi.org/10.5065/D6RR1W7M, 2013.

Polashenski, C. M., Dibb, J. E., Flanner, M. G., Chen, J. Y., Courville, Z. R., Lai, A. M., Schauer, J. J., Shafer, M. M., and Bergin, M.: Neither dust nor black carbon causing apparent albedo decline in Greenland's dry snow zone: Implications for MODIS C5 surface reflectance, Geophys. Res. Lett., 42, 93199327, 2015. 
Qian, Y., Wang, H., Zhang, R., Flanner, M. G., and Rasch, P. J.: A sensitivity study on modeling black carbon in snow and its radiative forcing over the Arctic and Northern China, Environ. Res. Lett., 9, 064001, https://doi.org/10.1088/1748-9326/9/6/064001, 2014.

Rignot, E. and Kanagaratnam, P.: Changes in the velocity structure of the Greenland Ice Sheet, Science, 311, 986-990, 2006.

Rignot, E., Velicogna, I., van den Broeke, M. R., Monaghan, A., and Lenaerts, J. T.: Acceleration of the contribution of the Greenland and Antarctic ice sheets to sea level rise, Geophys. Res. Lett., 38, L05503, https://doi.org/10.1029/2011GL046583, 2011.

Shepherd, A., Ivins, E. R., Geruo, A., Barletta, V. R., Bentley, M. J., Bettadpur, S., Briggs, K. H., Bromwich, D. H., Forsberg, R., and Galin, N.: A reconciled estimate of ice-sheet mass balance, Science, 338, 1183-1189, 2012.

Shimada, R., Takeuchi, N., and Aoki, T.: Inter-annual and geographical variations in the extent of bare ice and dark ice on the Greenland ice sheet derived from MODIS satellite images, Front. Earth Sci., 4, 43, https://doi.org/10.3389/feart.2016.00043, 2016.

Tedesco, M.: Snowmelt detection over the Greenland ice sheet from SSM/I brightness temperature daily variations, Geophys. Res. Lett., 34, L02504, https://doi.org/10.1029/2006GL028466, 2007.
Tedesco, M., Doherty, S., Fettweis, X., Alexander, P., Jeyaratnam, J., and Stroeve, J.: The darkening of the Greenland ice sheet: trends, drivers, and projections (1981-2100), The Cryosphere, 10, 477-496, https://doi.org/10.5194/tc-10-477-2016, 2016.

Thomas, J. L., Polashenski, C. M., Soja, A. J., Marelle, L., Casey, K., Choi, H. D., Raut, J. C., Wiedinmyer, C., Emmons, L. K., and Fast, J.: Quantifying black carbon deposition over the Greenland ice sheet from forest fires in Canada, Geophys. Res. Lett., 44, https://doi.org/10.1002/2017GL073701, 2017.

van den Broeke, M., Bamber, J., Ettema, J., Rignot, E., Schrama, E., van de Berg, W. J., van Meijgaard, E., Velicogna, I., and Wouters, B.: Partitioning recent Greenland mass loss, Science, 326, 984 986, 2009.

Vaughan, D. G., Comiso, J. C., Allison, I., Carrasco, J., Kaser, G., Kwok, R., Mote, P., Murray, T., Paul, F., and Ren, J.: Observations: cryosphere, in Climate Change 2013, 2103, 317-382, 2013.

Viovy, N.: CRU-NCEP Version 4, available at: http://dods.extra. cea.fr/data/p529viov/cruncep/V4_1901_2012/ last access: August 2012.

Zwally, H. J., Abdalati, W., Herring, T., Larson, K., Saba, J., and Steffen, K.: Surface melt-induced acceleration of Greenland icesheet flow, Science, 297, 218-222, 2002. 